\title{
Ambasador Produk dan Perubahan Sikap \\ (Studi Kasus Pengolahan Iklan Kosmetik XYZ Berdasarkan Pendekatan Teori ELM di Kalangan Remaja Putri Kelurahan Rawa Buaya - Jakarta Barat)
}

\author{
Inge Hutagalung ${ }^{1}$ \\ Universitas Mercu Buana, Jakarta, Indonesia \\ J1. Meruya Selatan No.1, Kembangan, Jakarta 11650 \\ I'inge_hutagalung@mercubuana.ac.id
}

\begin{abstract}
This study used a qualitative approach. Method of data collection in the research conducted through indepth interviews with selected informants. The aim of the research was to see the processing of messages from ads that use the ambasador products among young women. The research results showed that peripheral route message processing is not always describe the low motivation of individuals against advertising messages. Meanwhile, the change in attitude is also not always only on individuals who manipulate the message by using the central route.. Further, the environment/peer group can play a role in the processing of the message. A sense of pride that appears on informants to cultivate messages line the periphery is the perceptual style. That is, a behavior that gave rise to the interpretation that the products represented by ambasador is a good one. In this case, each interpretation would produce a different meaning to the one and other people.
\end{abstract}

Keywords: Ambassador, Peripheral route, Peer group

\begin{abstract}
Abstrak
Penelitian ini menggunakan pendekatan kualitatif. Metode pengumpulan data dalam riset dilakukan melalui wawancara mendalam dengan informan terpilih. Tujuan dari penelitian adalah untuk melihat pengolahan pesan dari iklan yang menggunakan ambasador produk di kalangan remaja putri. Hasil penelitian memperlihatkan bahwa pengolahan pesan secara jalur pinggiran tidak selamanya menggambarkan motivasi yang rendah dari individu terhadap pesan iklan. Sementara itu, perubahan sikap juga tidak selamanya hanya terdapat pada individu yang mengolah pesan dengan menggunakan jalur utama. Lebih lanjut, lingkungan/kelompok sebaya dapat berperan dalam pengolahan pesan. Rasa bangga yang muncul pada informan yang mengolah pesan secara jalur pinggiran adalah merupakan perceptual style. Yaitu, sebuah perilaku yang melahirkan interpretasi bahwa produk yang diwakili oleh ambasador produk adalah berkualitas. Dalam hal ini, setiap interpretasi akan menghasilkan makna yang berbeda satu dan lain orang. Kata kunci: Ambasador, Jalur pinggiran, Kelompok sebaya
\end{abstract}

Copyright @ 2018 Ikatan Sarjana Komunikasi Indonesia. All rights reserved

\section{PENDAHULUAN}

Kehidupan manusia di dunia ini tidak dapat dilepaskan dari aktifitas komunikasi, karena komunikasi merupakan bagian integral dari sistem dan tatanan kehidupan social --manusia dan masyarakat -- sebagaimana dinyatakan filsuf Belanda, Baruch Spinoza: manusia adalah mahluk sosial yang cenderung selalu hidup bermasyakat dan berperilaku selaras dengan lingkungannya (Hutagalung, 2016). Dalam kaitan itu, aktifitas komunikasi dapat terlihat pada setiap aspek kehidupan sehari-hari manusia, dan juga merupakan alat manusia untuk bertahan hidup.

Salah satu bentuk komunikasi dalam kehidupan manusia adalah pemasaran. Pemasaran dengan komunikasi memiliki hubungan yang erat. Dasar dari pemasaran adalah komunikasi, dan pemasaran itu sendiri adalah sebuah konsep komunikasi. Pemasaran bisa akan begitu powerful jika 
dipadukan dengan komunikasi yang efektif dan efisien. Tidak ada sebuah perusahaan akan berhasil menawarkan produk tanpa menetapkan strategi komunikasi yang baik kepada konsumen. Komunikasi membantu perusahaan menyampaikan pemikiran, pemahaman maupun pesan tentang suatu konsep ataupun produk untuk disampaikan kepada masyarakat ataupun konsumen.

Melalui penyampaian pesan kepada konsumen diharapkan komunikasi yang dilakukan akan menghasilkan tiga tahap perubahan, yaitu perubahan knowledge (pengetahuan), perubahan sikap, dan perubahan tindakan yang dikehendaki. Tahapan pertama adalah tahap perubahan pengetahuan (awareness change). Dalam perubahan ini, konsumen mengetahui keberadaan sebuah produk, untuk apa produk diciptakan, dan ditujukan pada siapa. Dengan demikian, pesan yang disampaikan menunjukkan informasi penting dari produk itu. Tahap kedua adalah tahapan perubahan sikap (attitude change), yang ditentukan oleh tiga unsur, yaitu cognition (pengetahuan), affection (perasaan), dan conation (perilaku). Jika ketiga komponen ini menunjukkan adanya kecenderungan perubahan maka akan mungkin sekali akan terjadi perubahan sikap berupa keinginan mencoba produk. Adapun tahapan ketiga adalah tahap perubahan perilaku (loyalty change), dimaksudkan agar konsumen tidak beralih pada produk lain, dan terbiasa menggunakannya atau yang biasa disebut dengan loyalitas pelanggan (Kottler, 2009).

Salah satu bentuk penyampaian pesan dalam komunikasi pemasaran adalah iklan (advertising). Iklan dapat diartikan sebagai setiap bentuk komunikasi nonpersonal mengenai suatu organisasi, produk, servis, atau ide yang dibayar oleh satu sponsor yang diketahui. Adapun maksud 'dibayar' menunjukkan fakta bahwa suatu pesan iklan pada umumnya harus dibeli. Maksud kata 'nonpersonal' berarti suatu iklan melibatkan media massa yang dapat mengirimkan pesan kepada sejumlah besar kelompok individu pada saat bersamaan. Iklan merupakan salah satu bentuk promosi yang paling dikenal dan paling banyak dibahas orang, hal ini kemungkinan karena daya jangkaunya yang luas.

Kontroversi kerap berkembang di seputar keberadaan iklan berkaitan dengan kenyataan, bahwa di dalam iklan seringkali terdapat jurang antara apa yang diinformasikan tentang sebuah produk, dengan realitas produk itu sesungguhnya. Iklan, kerap kali menampilkan realitas yang tidak sesungguhnya dari sebuah produk. Iklan menampilkan realitas palsu. Dengan cara yang demikian, iklan telah melakukan sebuah kebohongan terhadap publik. Iklan justru terperangkap di dalam skema permainan tanda (free play of signs,) dalam rangka menciptakan citra palsu sebuah produk, yaitu citra yang sesungguhnya tidak merupakan bagian integral, subtansial, atau fungsional produk tertentu, akan tetapi lewat kemampuan retorika sebuah iklan, citra-citra tersebut justru menjadi model rujukan dalam mengkonsumsi sebuah produk.

Menilik bahwa iklan kerap terperangkap dalam skema permainan tanda dan menampilkan 'topeng realitas', dewasa ini muncul pendekatan iklan dengan menggunakan ambasador, yaitu sosok selebriti yang di "tugaskan" untuk selalu tampil menggunakan produk sekaligus menjadi duta produk. Kondisi ini menimbulkan pertanyaan mendasar terkait bagaimana khalayak memproses iklan yang menggunakan ambasador tersebut?

Apakah khalayak tetap akan melihat isi pesan iklan ataukah hanya akan melihat penampilan sosok ambasador pada iklan produk. Apakah iklan yang menggunakan ambasador akan dapat memicu perubahan sikap? Pertanyaan-pertanyaan terkait penggunaan ambasador produk ini menarik untuk diteliti lebih lanjut. 


\section{KERANGKA TEORITIS}

Penelitian dilakukan terkait pengolahan pesan berdasarkan teori ELM (Elaboration Likelihood Model) yang diperkenalkan oleh Richard Petty dan John Cacioppo. Gagasan-gagasan awal mengenai ELM ditulis oleh Petty dan Cacioppo pada awal tahun 1980-an, dan dielaborasi secara mendetail dalam buku berjudul Communication and Persuasion: Central and Peripheral routes to Attitude Change (1986). Teori ELM merupakan rangkuman umum dari insight teori-teori perubahan sikap lainnya. Teori ini adalah teori persuasi yang paling populer saat ini, paling banyak dipakai terutama dalam menjelaskan mengenai perubahan sikap setelah menerima pesan persuasi.

Petty dan Cacioppo (2005) melihat dua aspek penting yang menentukan bagaimana pesan persuasi itu diproses oleh seseorang. Pertama, motivasi seseorang dalam menerima pesan persuasi. Menurut Petty dan Cacioppo, motivasi seseorang berbeda-beda ketika menerima pesan. Perbedaan ini ditentukan oleh relevansi dari pesan persuasi itu bagi kebutuhan (baik fisik ataupun psikologis) seseorang. Makin tinggi relevansi pesan itu bagi seseorang, makin tinggi pula motivasi seseorang dalam menerima pesan, dan keinginan untuk mengetahui isi pesan. Kedua, kemampuan (ability) seseorang dalam memproses pesan persuasi.

Seseorang bisa jadi tertarik dan punya motivasi untuk memproses suatu pesan, tetapi jika orang tersebut tidak mempunyai kemampuan dalam memproses pesan, maka pesan persuasi itu juga tidak akan diproses.

Suatu pesan persuasi yang diolah dan dielaborasi, oleh Petty dan Cacioppo disebut menggunakan jalur utama (central route). Sebaliknya, suatu pesan persuasi yang tidak dielaborasi akan diproses menggunakan jalur pinggiran (peripheral route). Elaborasi atau pemikiran kritis terjadi pada rute sentral, sementara non elaborasi atau pemikiran yang kurang kritis terjadi di rute peripheral. Pada saat motivasi tinggi, seseorang akan cenderung untuk menggunakan rute sentral. Ketika seseorang menggunakan rute sentral, maka yang bersangkutan akan berargumen secara hatihati, dan juga akan mempengaruhi sikap. Keadaan sebaliknya akan terjadi, yaitu ketika seseorang mempunyai motivasi rendah maka akan digunakan rute peripheral dan tidak akan ada pengaruh banyak terhadap sikap diri.

Teori ELM didasarkan pada premis bahwa pesan persuasi (kampanye, iklan dsb) tidak diterima sama oleh khalayak. Pesan yang sama bisa diterima secara berbeda, dan pada akhirnya mempunyai efek yang berbeda bagi masing-masing individu. Orang mempunyai kemampuan yang terbatas dalam menerima pesan persuasi. Kemampuan memori dan mengolah pesan terbatas, sementara tiap hari seseorang berhadapan dengan ratusan bahkan ribuan pesan dari mulai iklan di media, spanduk di jalan, dan sebagainya.

\section{METODE PENELITIAN}

Penelitian ini menggunakan pendekatan kualitatif. Metode pengumpulan data dalam riset kualitatif dapat dilakukan melalui observasi, partisipasi, wawancara, dan etnografi (Neuman, 2006). Data primer dalam penelitian diperoleh melalui wawancara mendalam dengan informan terpilih, dan data sekunder diperoleh melalui studi pustaka maupun analisis dokumen.

Wawancara dilakukan secara mendalam dengan menggunakan pertanyaan yang tidak berstruktur yang dimulai dengan kata tanya yang bersifat terbuka, seperti: bagaimana, apakah, dan mengapa. Wawancara mendalam akan terus dilakukan sampai peneliti mendapatkan informasi baik dari segi kualitas maupun kelengkapan informasi yang dibutuhkan. Argumentasi dipilihnya wawancara mendalam karena pertanyaan yang diajukan bersifat pribadi. 
Informan penelitian terdiri dari tujuh orang remaja putri SMA dari Kelurahan Rawa Buaya, Jakarta Barat. Alasan dipilihnya remaja putri karena merupakan pengguna produk kosmetik terbesar. Pengambilan kasus kosmetik XYZ karena merupakan kosmetika pertama di Indonesia yang mengusung konsep produk Islami yang halal. Sementara batasan mengenai remaja, penelitian ini mengambil definisi berdasarkan Undang-Undang yang berlaku di Indonesia, yaitu UndangUndang No.4 tahun 1979 dan Undang-Undang Perburuhan. Yaitu, usia remaja adalah mereka yang berada pada usia 16 hingga 20 tahun (dibawah usia 21 tahun).

\section{HASIL PENELITIAN}

Hasil penelitian memperlihatkan bahwa para informan mengolah pesan iklan secara berbeda-beda. Empat informan menyatakan bahwa pengolahan pesan iklan pada umumnya dilakukan secara cermat manakala dirasakan bahwa iklan adalah informasi yang dibutuhkan untuk membantu memecahkan masalah. Contoh, ketika ingin makan bareng teman dengan dana yang terbatas maka iklan yang menawarkan tempat nyaman dengan harga yang murah akan diperhatikan.

Sementara tiga informan menyatakan bahwa pengolahan pesan iklan dilakukan terpengaruh pada sosok model iklan. Contoh, ketika ingin makan bareng teman kemudian ada iklan Raffi Ahmad sedang makan bareng di sebuah resto maka iklan Raffi Ahmad tersebut menjadi menarik untuk dibaca. Argumentasi ketiga informan terhadap hal ini adalah karena mereka ingin up date terhadap resto baru yang di kunjungi para artis.

Lebih lanjut, menjawab pertanyaan terkait apa yang menarik dari iklan produk kosmetik XYZ, ketujuh informan menyatakan bahwa kehalalan dari produk kosmetik adalah merupakan hal utama yang menarik dari pesan iklan kosmetik XYZ. Adapun menjawab frekwensi melihat iklan produk kosmetik XYZ, para informan menyatakan kerap melihat iklan produk XYZ, baik secara sengaja maupun tidak sengaja (standing banner banyak di Mall/Pasar).

Menjawab pertanyaan terkait apakah keberadaan ambasador pada iklan produk kosmetik XYZ menjadi pemikat untuk mengolah iklan lebih lanjut. Hanya tiga informan yang menyatakan bahwa sosok ambasador membuat iklan produk kosmetik XYZ semakin menarik untuk diolah. Sementara empat informan lainnya menyatakan keberadaan sosok ambasador tidak menjadi alasan utama untuk mengolah iklan produk lebih lanjut. Argumentasi yang diberikan oleh keempat informan adalah karena sosok ambasador bisa dan kerap berubah-ubah dalam durasi waktu tertentu.

Sementara itu, terkait pertanyaan peran ambasador terhadap peningkatan pengetahuan produk, tiga informan menyatakan setuju bahwa ambasador dapat meningkatkan pengetahuan produk. Argumentasi yang disampaikan karena iklan yang menggunakan ambasador lebih menarik untuk dilihat dan kerap dilengkapi audio visual berupa ungkapan kata2 (tagline) dari sosok ambasador. Sementara itu, empat informan menyatakan kurang setuju. Adapun argumentasi yang disampaikan adalah peningkatan pengetahuan dapat dicapai tergantung pada redaksional iklan, dan bukan pada sosok ambasador produk.

Lebih lanjut, terkait pertanyaan peran ambasador terhadap perubahan sikap. Jawaban para informan terbelah dua: sebanyak empat informan menyatakan bahwa penampilan ambasador dalam sebuah iklan belum tentu dapat membuat konsumen melakukan perubahan sikap. Argumentasi yang diberikan karena ambasador adalah bagian dari promosi produk melalui iklan, sehingga kerap kali penampilan ambasador cenderung terkesan dibuat-buat untuk mengungguli produk yang diwakilinya. Sementara itu, tiga informan menyatakan bahwa ada kecenderungan perubahan sikap manakala melihat sebuah produk dipakai oleh sosok ambasador. Perubahan sikap dipicu oleh 
timbulnya perasaan bangga jika dapat menggunakan produk yang juga dipakai oleh ambasador yang seyogyanya adalah selebriti.

Menjawab pertanyaan peran ambasador terhadap perubahan perilaku. Para informan menyatakan bahwa perubahan perilaku untuk menjadi konsumen yang loyal akan membutuhkan waktu yang panjang, dan tidak ditentukan oleh sosok ambassador. Lebih lanjut, ketujuh informan menyatakan bahwa mungkin saja akan terjadi perubahan perilaku pilihan produk kosmetik kemerek yang lain dikarenakan sosok selebriti yang menjadi ambasador produk juga mengalami pasang-surut ketenaran dan tidak menutup kemungkinan akan munculnya idola baru. Selain itu, trend kosmetik yang selalu berubah-ubah membuat sikap konsumen juga akan berubah-ubah mengikuti mode.

Menjawab pertanyaan apakah ada hal lain yang berperan dalam proses pengolahan pesan sebuah iklan? Empat informan menyatakan bahwa sangat memerhatikan dukungan kelompok terkait pengolahan sebuah informasi. Informasi yang mendapatkan dukungan kelompok akan menjadi pilihan, sementara informasi yang kurang mendapatkan dukungan akan dihindari ataupun ditolak.

Dalam kasus iklan produk kosmetik, kempat informan menyatakan akan menghindari informasi iklan manakala dukungan kelompok terhadap iklan melemah. Penghindaran yang dilakukan adalah wujud upaya untuk mencapai keseimbangan dengan kelompok. Keempat informan menyadari bahwa sebuah penyimpangan dari kelompok akan menimbulkan sanksi sosial/moral, seperti pengucilan dari kelompok, dikeluarkan dari kelompok, cemoohan hingga hukuman pidana. Dan sebaliknya, para informan menyatakan akan mencari dan mengunduh informasi iklan manakala dukungan kelompok terhadap informasi menguat. Ditegaskan para informan bahwa mereka mengunduh informasi iklan yang juga diakses oleh rekan sebaya dengan alasan mengikuti trend dan tidak ingin dianggap kuno.

Terkait penting atau tidaknya penampilan sosok seorang ambasador pada sebuah iklan produk kosmetik XYZ, pendapat para informan terbagi dua. Tiga informan menyatakan bahwa sosok ambasador adalah penting. Adapun argumentasi yang diberikan adalah bahwa ambasador dapat lebih meyakinkan diri bahwa produk kosmetik XYZ adalah produk yang terkualitas dan digunakan oleh selebritas. Sementara sisanya menyatakan kurang penting dengan argumentasi bahwa ambasador hanyalah pelengkap dari informasi iklan belaka.

\section{PEMBAHASAN}

Hasil penelitian memperlihatkan bahwa pengolahan pesan terhadap iklan produk kosmetik XYZ yang menggunakan ambasador dengan menggunakan pendekatan teori ELM terbagi atas dua kelompok. Pertama, kelompok informan yang mengolah pesan iklan menggunakan jalur utama, yaitu kelompok yang mengolah pesan berdasarkan isi pesan dan bukan penampilan ambasador produk.

Kedua, pengolahan pesan iklan yang menggunakan jalur pinggiran. Yaitu, kelompok yang mengolah pesan berdasarkan penampilan sosok ambasador produk.

Menurut peneliti, ada dua hal yang menarik dari hasil penelitian. Pertama, informan yang mengolah pesan iklan dengan jalur pinggiran memiliki ketertarikan pada iklan produk melalui sosok ambasador. Hal ini berbeda dengan pemikiran teoritik Petty dan Cacioppo dalam teori ELM yang menyatakan bahwa individu yang mengolah pesan dengan menggunakan jalur pinggiran 
adalah seseorang tidak mempunyai keinginan (motivasi) untuk menerima iklan. Pada penelitian ini tergambarkan bahwa tiga informan yang mengolah pesan iklan produk kosmetik XYZ dengan jalur pinggiran menyatakan bahwa sosok ambasador membuat iklan produk kosmetik XYZ semakin menarik untuk diolah pesannya. Kedua, informan yang mengolah pesan dengan jalur pinggiran menyatakan cenderung berubah sikap karena sosok ambasador produk. Hal ini berbeda dengan pemikiran teoritik Petty dan Cacioppo dalam teori teori ELM yang menyatakan bahwa perubahan sikap tidak tidak akan banyak terjadi pada individu yang mengolah pesan dengan jalur pinggiran.

Menyikapi kedua hasil penelitian tersebut di atas, peneliti mengemukakan pemikiran teoritik Littlejohn (2010) yang menjelaskan bahwa informasi merupakan hasil dari interaksi sosial dan perilaku pengolahan pesan merupakan bagian dari sistem kognitif, yaitu, apa yang dilakukan individu dalam situasi komunikasi tidak hanya tergantung pada bentuk informasi yang diterima, tetapi juga pada operasi mental yang digunakan untuk mengolah informasi. Dengan kata lain, ada dua faktor yang memengaruhi proses pengolahan pesan pada individu yaitu kemampuan pengolahan pesan dan faktor psikologis. Bahwa manusia dalam melakukan pengolahan informasi tidak hanya dipengaruhi oleh kemampuan diri dalam pengolahan pesan namun juga dipengaruhi oleh faktor psikologis, yaitu interaksi sosial yang dilakukan sebagai perwujudan dari mahluk sosial.

Dalam hal ini, menurut peneliti --- interaksi sosial yang dilakukan terkait iklan produk XYZ sebagai produk kosmetik berlabel halal pertama di Indonesia telah membuat informan menjadi tidak perlu terlalu ktitis dalam menyikapi keberadaan produk. Akibatnya operasi mental (kognitif) yang digunakan untuk mengolah informasi, dilakukan dengan menggunakan jalur pinggiran dan memiliki kecenderungan terhadap perubahan sikap diri.

Sementara itu, para informan yang mengolah pesan iklan dengan jalur pinggiran juga menyatakan bahwa perubahan sikap diri yang terjadi juga disebabkan adanya rasa bangga menggunakan kosmetika yang digunakan oleh ambasador (yang sejogyanya adalah selebriti). Peneliti berpendapat kondisi ini sesuai dengan pemikiran teoritik Littlejohn (2010) yang menyebut bahwa sejumlah penyebab, seperti penyebab situasional (perilaku tertentu dipengaruhi oleh lingkungan), pengaruh personal (perilaku dipengaruhi oleh penyebab personal), kemampuan (mampu melakukan sesuatu), usaha (mencoba melakukan sesuatu), sentimen (menyukai sesuatu), kewajiban (merasa bertanggungjawab atas sesuatu), dan sebagainya --- dapat memicu perubahan sikap diri.

Lebih lanjut, Heider (melalui teori atribusi) menyatakan bahwa antara perilaku yang diamati dengan penyebab tidaklah selamanya merupakan hubungan yang tunggal. Sebuah perilaku dipersepsi sebagai hasil dari penyebab tunggal, atau kebalikannya satu perilaku dapat muncul dari sejumlah penyebab. Persepsi tentang sebab-akibat (causal perception) dimediasi oleh sejumlah variabel dalam diri secara psikologis. Satu diantaranya adalah pemaknaan terhadap realitas. Individu selalu memberikan makna atas apa yang diamati dan ini adalah titik penting untuk menyatakan apa yang 'dilihat'. Makna menolong pengintegrasian persepsi seseorang, dan mengorganisasikan pengamatan ke dalam suatu pola tertentu, yang nantinya akan menolong individu dalam memahami realitas. Karena dibutuhkan konsistensi, individu mendefinisikan sesuatu dengan pola tertentu sehingga atribusi menjadi terintegrasi dan tampak konsisten. Fritz Heider menyebut bentuk dari persepsi individu itu sebagai perceptual style, yaitu bahwa sebuah perilaku bisa jadi akan melahirkan beragam interpretasi, dimana setiap interpretasi akan menghasilkan makna yang berbeda satu dan lain orang. 
Terkait dengan hasil penelitian yang dilakukan, informan yang mengolah pesan iklan produk kosmetik XYZ memiliki persepsi bahwa produk yang terwakili oleh ambasador adalah berkualitas.

Lebih lanjut, berdasarkan hasil penelitian tergambarkan bahwa parainforman merupakan bagian dari kelompok yang berbeda, yaitu mandiri dan terikat pada kelompok sebaya. Informan yang mandiri cenderung lebih fleksibel dalam menyikapi kehadiran sosok ambasador produk. Sementara informan yang terikat pada kelompok sebaya lebih menyikapi kehadiran sosok ambassador produk berdasarkan "konsensus" kelompok sebaya.

Peneliti berpendapat bahwa hal ini merupakan gambaran dari kehadiran individu sebagai mahluk sosial yang mengolah informasi dengan melibatkan sistem kognisi diri disamping turut memerhatikan lingkungan sosial di sekitar kehidupannya, yaitu sebagai bagian dari kelompok sebaya maka ada norma-norma kelompok yang harus ditaati. Mana kala norma-norma tersebut dilanggar oleh individu yang menjadi anggota/bagian dari kelompok maka akan timbul sanksi yang dapat merupakan sanksi sosial (berupa hukuman sosial, seperti dikucilkan, dikeluarkan dari keanggotaan) maupun sanksi moral (seperti perasaan bersalah, berdosa dan lainnya).

Terkait pada perubahan perilaku, hasil penelitian memperlihatkan bahwa penampilan ambasador akan memudar seiring menurunnya popularitas, karena itu peran ambasador tidak dirasakan cukup oleh para informan untuk melakukan perubahan perilaku konsumen terhadap sebuah produk.

\section{KESIMPULAN}

Pengolahan pesan pada iklan produk yang menampilkan sosok ambasador dapat diolah melalui pemikiran kritis (jalur utama) maupun pemikiran non kritis (jalur pinggiran).

Pengolahan pesan secara jalur pinggiran tidak selamanya menggambarkan motivasi yang rendah dari individu terhadap pesan iklan. Sementara itu, perubahan sikap juga tidak selamanya hanya terdapat pada individu yang mengolah pesan dengan menggunakan jalur utama.

Di sisi lain, kebanggaan yang muncul pada informan yang mengolah pesan secara jalur pinggiran adalah merupakan perceptual style, yaitu, sebuah perilaku yang melahirkan interpretasi bahwa produk yang diwakili oleh ambasador produk adalah berkualitas. Dalam hal ini, setiap interpretasi akan menghasilkan makna yang berbeda satu dan lain orang.

Lebih lanjut, lingkungan/kelompok sebaya dapat berperan dalam pengolahan pesan. Hal ini dapat dipahami mengingat pola budaya kolektivisme yang cenderung masih dianut oleh mayoritas masyarakat di Indonesia. Pada budaya kolektivisme, pengambilan keputusan kerap ditentukan oleh norma masyarakat ataupun pandangan yang bersifat interdependensi dengan senantiasa mengutamakan keharmonisan hubungan dalam kelompok. Berbeda dengan budaya individualisme dimana pengambilan keputusan banyak dirancang oleh pribadi, bersifat rasional dan mandiri karena keputusan dilakukan atas pertimbangan diri sendiri (lihat penelitian Markus dan Kitayama, 1991; Etsuko dan rekan, 2005).

Pengolahan pesan pada iklan yang memiliki ambasador produk yang menggunakan jalur utama maupun jalur pinggiran, cenderung tidak akan membuat individu melakukan perubahan perilaku. Hal ini dikarenakan produk kosmetik sebagai produk yang diiklankan merupakan jenis produk yang berkembang dan berubah terus sesuai dengan tren mode. Di sisi lain, ambasador produk juga memiliki kerentanan terkait popularitas yang dimiliki. 


\section{Daftar Pustaka}

Hoshino, Etsuko \& Zanna, Adam. S. 2005. On The Cultural Guises of Cognitive Dissonance :The Case of Easteners and Westerners. Journal of Personality and Social Psychology, 89.

Hutagalung, Inge. 2016. Disonansi Kognitif pada Perilaku Seks Pranikah. Jurnal Komunikasi Ikatan Sarjana Komunikasi Indonesia. Vol 1(2): 71-80.

Kotler, Philip., Keller, Kevin Lane. 2009.

Marketing Management. New Jersey:Pearson Education, Inc.

Littlejohn, Stephen W, Foss, Karen. 2010.

Theories of Human Communication, 10 Edition, Belmont, CA: Wadsworth.

Markus. H., Kitayama. S. 1991. Culture and

The Self: Implications for Cognition, Emotion andMotivation.Psychological Review, 2, 224253.

Neuman, W. Laurence. 2006. Social Research Methods: Qualitativer and Quantitative Approaches. Fourth Edition, Berlmont.

Petty, Richard, Joseph R. Priser and Pablo Brinol. 2002. Mass Media Attitude

Change: Implications of the Elaboration Likelihood Model of Persuasion.

Jennings Bryant and Dolf Zillmann (ed).

Media Effect: Advances in Theory and Research, Second Edition, Mahwah, New Kersey: Lawrence Erlbaum.

Petty, Richard, John T Stratham and Joseph

Priester.2005. To thinks or Not to Thnink: Exploring Twi Routes to Persuasion.

Timothy C. Brock and Melanie C. Green (ed). Persuasion, Psychological Insights and Perspectives, Second Edition, Thousand Oaks : Sage Publications

Tankard, James W Jr. dan Werner J. Severin.2008. Teori Komunikasi, Jakarta, Preanada Media Group. 